\title{
OKTATÁSI RENDSZER EGY DEMOKRATIKUS DIKTATÚRÁBAN
}

\author{
TÓTH ADRIENN ANITA
}

ELTE PPK Gyógypedagógiai Program

Xiaozhou Xu \& Weinui Mei: Educational Policies and Legislation in China. Singapore, 2018. Springer. xvii + 267 p. ISBN 978-981-13-0875-8

$\mathrm{Az}$ OECD adatai alapján Kína lakossága jelenleg 1 milliárd 385,6 millió fö. ${ }^{1} \mathrm{Nem}$ véletlen, hogy amikor a kínai oktatásról olvasunk, olyan adatok kerülnek a szemünk elé, amilyeneket még elképzelni is nehéz sokszor, nemhogy a mindennapok valóságának tekinteni. Egy Európa-méretű ország oktatásügyét megszervezni - több mint 200 millió diákkal, közel 15 millió tanárral - már önmagában lenyügöző vállalkozás. Ha mindehhez hozzáveszszük, hogy az 1970-es évek végétől a kínai az egyik leggyorsabban fejlődő gazdaság, akkor további elképesztő számadatokkal, GDP-értékekkel, százalékos ráfordításokkal szembesülhetünk. Xiaozhou Xu és Weihui Mei könyvükben részletesen bemutatják az ókori gyökerektől napjainkig a kínai oktatásügy változásait, mérföldköveit, irányelveit, hogy betekintést nyerjünk a hihetetlen számok mögé.

$\mathrm{A} z$ oktatásügy helyzete sokat változott az országban, a legnagyobb változások a 20. századhoz kapcsolódnak. A tradíció sokáig meghatározta az oktatás tu-

https://data.oecd.org/china-people-s-republicof.htm\#profile-education/ [Letöltve: 2019. 06. 16.] lajdonságait, Kína történelme rendkívül gazdag, ókori nagy filozófusaik, tudósaik hatása vitathatatlan. Világszerte találkozhatunk az alábbi két megközelítési móddal, ha az oktatás szerepét vizsgáljuk. $\mathrm{A} z$ egyik, a társadalmi alapú, azt hangsúlyozza, hogy az oktatásnak elsősorban a társadalom igényeit kell figyelembe vennie, és az egyén igényei csak ezután következhetnek. Az oktatásnak pedig a két legfontosabb célja, hogy a fiatalokból jó polgárokat neveljen, illetve hogy biztosítsa a társadalmi stabilitást. A közösségi jóllét tehát mindig előbbre való az egyéninél. A másik megközelítés az egyénre, a személyre teszi a hangsúlyt, eszerint a legfontosabb, hogy az egyén érdeklődésének megfelelően, az ő igényei, érdeklődési körei, képességei szerint alakuljon az oktatás. A kínai családok életében, felfogásában mindig is központi helyet foglalt el a tanulás, mint egy lehetséges út a felemelkedésre, ugyanakkor általánosan azt a megközelítést vallják, hogy a legfontosabb cél a társadalmi jóllét megteremtése, és a legfőbb kérdés az, hogy az egyén tudása révén hogyan tudja szolgálni ezt. $\mathrm{Az}$ egyik legrégibb oktatással foglalkozó mü írója, Xue Ji így fogalmazza ezt meg: 
„Ha államot akarsz alapítani és embereken uralkodni, elsőként az oktatással kell foglalkoznod." (3. o.) A szerzők ezzel a gondolattal hozzák párhuzamba Deng Xiaoping 1977-ben tett nyilatkozatát, melyben kifejtette, hogy csak akkor érhető el gazdasági növekedés, ha különleges figyelmet szentelnek az oktatásnak. A következő évben meghirdetett nyitás politikának is alappillére volt, hogy modernizálni kell az oktatást, a tanítást, az iskolarendszert, ehhez a fejlett országok mérő eljárásait, minőségi sztenderdjeit kell használni, és ki kell aknázni a rendelkezésre álló humán erőforrást. Ettől az évtől kezdve elindult egy óriási fejlesztési időszak, amelyben politikák, projektek, cselekvési tervek követték egymást, és amely során az oktatási rendszer minden szintjén változtatások indultak el - köszönhetően az ország éves GDP-jéhez kötött százalékos ráfordítások folyamatos növekedésének. Kínában is felismerték, hogy az oktatás hosszú távú befektetés, melynek csak később nyilvánulnak meg a gazdaságra tett pozitív hozadékai, ezért arra törekedtek, hogy a gazdaságot és az oktatást párhuzamosan fejlesszék, hogy a bejövő forrásokból finanszírozni tudják az oktatási reformokat, abban bízva, hogy az itt létrejött változások majd pozitívan hatnak vissza. A reformok központi kérdése volt a minőség mérése, meghatározása mint a fejlődés biztosításának egyik fontos alapköve.

A minőség kérdésének bemutatását is az ókornál kezdik a szerzők, akik egészen a Shang-dinasztiáig nyúlnak vissza, a hat művészet (szertartások, költészet, ijászat, kocsihajtás, írás, matematika) idejére, amikor is az elméleti és gyakorlati ismereteket ötvözték. Az elvárások azonban nagyon magasak voltak, kevesen tudták megugrani a kívánt szintet, ráadásul nagyon keveseknek, csak a nemesi rétegnek volt egyáltalán lehetősége tanulni. Erre az időszakra nyúlik vissza a vizsgarendszer nagy presztízse is, a császári vizsgára bárki jelentkezhetett, ezért azt úgy tekintették, mint lehetőséget a szegényebb sorsú, tehetséges fiatalok felemelkedésére. Ez a fajta vizsgaközpontú szemlélet máig is jellemző. A hagyományokhoz való ragaszkodást jól mutatja, hogy a rendszer, ha változtatásokkal is, de egészen 1905-ig fennállt.

1949 előtt az alapfokú oktatás általános minősége gyenge volt: a szelekcióra, a legjobbak kiválasztására alapult, és nem a tömeges oktatás szintjének emelésére. Emellett a vizsgakérdésekre fókuszáltak, így hiányzott a kreativitás, és csökkent a tudás gyakorlati alkalmazhatóságának jelentősége. A legfőbb cél az volt, hogy minél több embert tudjanak bevonni az oktatásba, és lehetővé tegyék a társadalmilag és gazdaságilag elmaradottabb régiókban élők számára is a tanulást. A nyitást követő években, az első reformintézkedésekkel párhuzamosan, az oktatást befolyásolók figyelmet fordítottak a külföldi trendek megismerésére és a kínai helyzet széles körű feltárására. Ennek alapján 1993ban egy nagyszabású tervet dolgoztak ki, melynek legfontosabb alappillérei az alábbiak voltak:

- A kötelező kilencéves általános iskolai oktatás egységesítése országos szinten, a hozzáférés segítése a falvakban. A középiskolai oktatás elérhetősége a nagyobb városokban. Az óvodai rendszer elérhetőségének kiszélesítése.

- A középfokú oktatásban részt vevők számának növelése. A középfokú oktatásban megszerezhető szakképzettségek és a munkaerőpiaci igények összehangolása.

- A felsőoktatás színvonalának növelése érdekében a csúcsegyetemek és a tudományterületek fejlesztése.

- Az analfabetizmus megszüntetése a felnőtt lakosság körében. 
Ezeknek a céloknak az érdekében több szektort érintő tevékenységeket határoztak meg. Ezek közé tartozott az általános iskolai oktatás erősítése, melynek részét képezte az ellenőrző rendszer kiépítése, hogy az új intézkedések megvalósulását nyomon lehessen követni. Változtatni szerettek volna a vizsgaközpontú szemléleten az oktatási rendszer minden egyes szektorában. Az iskolai körülmények javításának érdekében egy általános kritériumrendszer kidolgozását tűzték ki, annak reményében, hogy ez megkönnyíti a megvalósítást és biztosítja a megfelelő körülményeket az ország teljes területén. A szakmai oktatás fejlesztése és népszerüsítése mellett a magas színvonalú képzések létrehozásának ösztönzését fogalmazták meg. Ehhez kulcsfontosságúnak ítélték meg a hálózatépítés elkezdését a szakképzéseket nyújtó iskolák között. Az oktatás sikerességének érdekében arra bíztatták a munkáltatókat, hogy vegyenek részt a tervezés folyamatában, hogy a képzések valódi munkaerőpiaci igényeket szolgáljanak ki, és megvalósulhasson az „elöször a képzés, utána a munka" elve.

A Nyugat felé nyitás politikai célkitüzései és az általános és középfokú oktatás reformjai a felsőoktatás számára is feladatokat jelöltek ki. A minőség javulása érdekében nekik is új útra kell lépniük, és egy hatékonyabb müködési keretet kell megfogalmazniuk. Ennek részét képezte, hogy minőségi szabványaikat az egyetemeknek és föiskoláknak közös együttmüködésben kell meghatározniuk, és a fejlődésben is támogatniuk kell egymást. Támogatniuk kell a helyi szakmai képzéseket annak érdekében, hogy onnan is érkezzenek diákok a felsőoktatásba. Meg kell erősíteni az alaptantárgyak körét, az új és peremtantárgyakat pedig a helyzetnek megfelelően kell fejleszteni. A központi és helyi hatalomnak ki kell választania azt a száz egyetemet, melyek kiemelt figyelmet kapnak, ahol képesek az oktatást és a kutatást a nemzetközi, a 21. századi kihívásoknak is megfelelő színvonalú szintre emelni. A felsőoktatás, de különösen a felnőttoktatás terén a gyakorlati tantárgyak számának növelését tüzték ki célul, hogy megerősítsék a hidat a tanulás és a munka között, növelve ezzel is a hatékonyságot.

A tervezetben nem feledkeztek el a már aktív dolgozókról sem, az ő folyamatos képzésüket, fejlődési lehetőségük biztosítását is ebben a rendszerben kívánták megvalósítani. A tervezetben szó esett a Kínában is nagy nehézségeket okozó országos eltérésekről, a vidék és a városok közötti különbségekről, melyek az egész program sikerességét befolyásolják. Felvázolták egy olyan együttmüködési rendszer lehetőségét, melyben a fejlettebb részek aktívan támogatják az elmaradottabb régiókat. Eszerint az elképzelés szerint a vidéki területek nem passzív befogadói a fejlesztéseknek, hanem aktívan keresik azokat a lehetőségeket, melyekkel ők is hozzá tudnak járulni a sikerességhez.

Külön érdekességük a kínai országos terveknek, hogy többször is megjelenik bennük az önkéntesek bevonása, illetve hogy a magasabban képzettek adják át tudásukat a többieknek. Bár nem kapnak központi szerepet a sajátos nevelési igényü gyermekek, fiatalok, felnőttek, de az ő helyzetük javítása is megtalálható ebben a kilencvenes évek eleji programban. Mind az integráció támogatásával, mind speciális intézmények létrehozásával szerették volna biztosítani a részvételüket az oktatásban. Felismerték, hogy a kitüzött célok elérését csakis úgy lehet megvalósítani, ha serkentik a módszertani megújulást. Ennek egyik alappilléreként jelent meg a nemzetközi kapcsolatok kiépítése. Itt két dolgot emelnék ki. Az egyik a kínai diákok ösztöndíjrendszere, mely támogatást nyújt külföldi tanulmányokhoz, illetve külföldi diákok befogadása a kínai rendszerbe. 
$\mathrm{A} z$ első esetében a könyvben többször is határozottan megjelenik az az elv, hogy a külföldi tapasztalatokat a diákok mindenképpen Kínában kamatoztassák. Ennek egyik érdekes megoldása, hogy az állam által finanszírozott, felsőoktatási képzettséget szerző diákok Kínában dolgozzanak, ráadásul az első időszakban egy elmaradottabb vidéken.

A reformok egyik fontos része volt a tanárok helyzetének kezelése. A célok között megfogalmazásra került a tanárok képzettségének növelése, a fizetések megemelése, a lakhatási körülményeik javítása és a társadalmi megítélésük javítása, a szakma presztízsének növelése. Ennek érdekében át kell alakítani a tanárképzést, hogy képesek legyenek a rendszer minden egyes szintjén a magas színvonalú oktatásra. Rendezni kell a fizetéseket, hogy azok versenyképesnek számítsanak egy vállalati fizetéssel összehasonlítva. A fizetéseknek tükrözniük kell a munka minőségét is.

A reformok finanszírozási alapját a GDP 4\%-a adta, a tervek szerint a huszadik század végéig ennyit kell fordítani az oktatásra. 1993-ban tehát ezek az elképzelések jelentették az oktatási reform gerincét. A rendszer minden egyes szintjén megtervezték a szükséges változtatásokat, meghatározták a cselekvési terveket és a végrehajtás ellenőrzését. A szektorok egymással szoros együttmüködésben valósították meg az elképzeléseket. Ettől az időszaktól kezdve különböző távlatokban fogalmaztak meg cselekvési terveket, melyeket újra és újra felül is vizsgáltak és korrigáltak.

2020-ig az alábbi célokat szeretnék elérni:

$\mathrm{A} z$ iskolát megelőző rendszer kialakítása, kétéves iskolaelőkészítő bevezetése, elterjesztése.

A kötelező oktatás elterjesztése jó ütemben haladt, de továbbra is fontos fel- adat, hogy elérjenek mindenkit. Emellett feladatnak tűzték ki, hogy csökkentsék a tanítványok terhelését az általános és a középiskolákban is. Ez egy folyamatosan napirenden lévő kérdés Kínában, nagyon nehéz megtörni a hagyományokat és változtatni nemcsak a szakemberek, hanem a lakosság szemléletén is.

A szakképzési rendszer fejlesztésében továbbra is számítanak a munkaadókra, a velük való együttmúködés kihagyhatatlan része a jövő terveinek is.

Elő kell segíteni az élethosszig tartó tanulást, az Európai Unió szakpolitikájában megjelenő tendenciáknak megfelelően, amihez nem elég az intézményi hálózat kiépítése, szükség van arra is, hogy biztosítsák a részvétel lehetőségét azoknak, akiknek az adott képzésre szükségük van. A kisebbségek számára is meg kell teremteni a lehetőséget az oktatásban való részvételre. Ebben a tervben is megjelennek a sajátos nevelési igényü gyermekek, fiatalok, a speciális iskolarendszer és az integráció bővítése.

Ezeken kívül hat főbb terület köré csoportosították a cselekvési terveket:

- Müveltség

- Vizsgáztatási és felvételi rendszer

- Modern iskolarendszer

- Iskolarendszer, beleértve az alapítványok, támogató szervezetek működését

- Adminisztrációs rendszer

- Nyitott kínai oktatás

A könyv azon részei, melyek a célok, távlatok leírását tartalmazzák, részletesen, statisztikai adatokkal mutatják be az előző periódusok sikereit, megvalósított törekvéseit. Érdekes az a része a münek, amelyben a nemzetközi kapcsolatokat és az ösztöndíjrendszert mutatja be. Jól látszik az az erőfeszítés, hogy a külföldön tapasztalatot szerzett diákok feltétlenül otthon kamatoztassák tudásukat, ráadásul lehetőség szerint egy-egy 
elmaradottabb régióban. Mindemellett mostanra $a z$ is fontos törekvéssé vált, hogy terjesszék a kínai nyelvet, és maguk is minél több külföldi diákot fogadjanak, különösen a környező országokból. Kínában is folyamatosan figyelik a nemzetközi trendeket, és igyekeznek beilleszteni politikájukba a releváns tartalmakat.
A mü egy óriási vállalkozás eredménye, a kezdetektől napjainkig mutatja be a kínai oktatási rendszer változásait, a reformelképzeléseket, azok eredményeit. Segítségével betekintést nyerhetünk a kínai siker mélyébe, megismerkedhetünk oktatásügyük alapfilozófiájával, szembesülhetünk a napi politika hatásával is.

A cikk a Creative Commons Attribution 4.0 International License (https://creativecommons.org/licenses/ by/4.0/) feltételei szerint publikált Open Access közlemény, melynek szellemében a cikk bármilyen médiumban szabadon felhasználható, megosztható és újraközölhető, feltéve, hogy az eredeti szerző és a közlés helye, illetve a CC License linkje és az esetlegesen végrehajtott módosítások feltüntetésre kerülnek. (SID_1) 